\title{
Promoting Mental Health among Lesbian, Gay, Bisexual, and Questioning Youth: Implications for Practice
}

\section{Gayle Mallinger, PhD}

Associate Professor, Department of Social Work, Western Kentucky University, 1906 College Heights Drive, Bowling Green, KY 42101, United States.

\author{
Article Details \\ Article Type: Research Article \\ Received date: $05^{\text {th }}$ February, 2021 \\ Accepted date: $30^{\text {th }}$ March, 2021 \\ Published date: $01^{\text {st }}$ April, 2021
}

"Corresponding Author: Gayle Mallinger, PhD, Associate Professor, Department of Social Work, Western Kentucky University, 1906 College Heights Drive, Bowling Green, KY 42101, United States.E-mail:gayle.mallinger@wku.edu

Citation: Mallinger, G. (2021). Promoting Mental Health among Lesbian, Gay, Bisexual, and Questioning Youth: Implications for Practice. J Ment Health Soc Behav 3(1):135. https://doi.org/10.33790/jmhsb110035

Copyright: $\odot 2021$, This is an open-access article distributed under the terms of the Creative Commons Attribution License 4.0, which permits unrestricted use, distribution, and reproduction in any medium, provided the original author and source are credited.

\begin{abstract}
The experiences of adolescents who identify as lesbian, gay, bisexual, and questioning (LGBQ) are situated in pervasive heterosexism. The potential for oppression of LGBQ youth of color and/or those holding non-Christian beliefs, are exponentially increased. Historical, social, political, and cultural contexts also influence experiences of marginalization. The ecological perspective, combined with risk and resilience theory, form a conceptual basis to clarify the reciprocal relationships between LGBQ youth and their environments. Together, these theories assist in locating optimal intervention points for mental health professionals, ensuring the best possible outcomes for this population. Utilizing these theoretical frameworks, the author discusses the importance of recognizing and advocating for strategies to promote health and mental well-being among LGBQ youth.
\end{abstract}

Keywords: Lesbian, Gay, Bisexual, Adolescent, Youth, Risk and Resilience, Ecological Theory

\section{Introduction}

Lesbian, gay, bisexual, and questioning (LGBQ) adolescents experience many of the same age-related concerns as their heterosexual counterparts, including strains in relationships with parents and demands to conform with peers. For youth struggling with stigmatized identities, however, these years can be filled with additional discord and tension. Although societal acceptance the LGBQ community has increased over the past several decades, oppression and discrimination still exist. All too often, LGBQ youth experience family conflict, mistreatment from peers, and isolation from communities. LGBQ youth continue to face considerable stressors, including rejection by parents and classmates, physical and sexual violence, homelessness, and inadequate social and organizational supports $[1,2]$. Consequently, these youth are at greater risk for negative health and mental health consequences, including depression, anxiety, and substance abuse [3].

Although much of the research on LGBQ youth focuses on disparities, it is essential to also focus on protective factors promoting well-being. This paper explores best practices with LGBQ youth and their families. Mental health professionals must recognize the needs of this group, including those further marginalized due to intersections of race, social class, and religious beliefs. This paper does not address practice with transgender youth, as gender identity refers to an individual's personal concept of self as male, female, a blend of both, or neither. Sexual orientation refers to sexual, romantic, and/or emotional attraction. Someone who is transgender may be straight, gay, lesbian, or bisexual, as sexual orientation is not dependent on gender identity.

\section{Theoretical and Conceptual Framework}

The ecological perspective, combined with risk and resilience theory, explains the reciprocal interactions between lesbian, gay, bisexual, and questioning (LGBQ) youth and their environments. Uniting these two paradigms is valuable, as they both recognize the robust relationship between individuals and their social milieu. Thus, these frameworks have utility in locating optimal intervention points for mental health professionals.

\section{Ecological Perspective}

The ecological perspective focuses on the combined influences of context on personal development, emphasizing the associations among social networks [4]. These connections can serve as obstacles or supports to LGBQ youth development. The ecological environment is comprised of nested systems, with the individual surrounded by increasingly distal levels of influence. Microsystems are defined as interactions of between individuals and their immediate environments, including family, peers, and school. Mesosystems refer to connections between various microsystems in which youth actively participate. Each person's unique traits, along with genetic factors, affect relationships with others. For example, a self-confident adolescent who identifies as bisexual and has parental support will have a different experience than a young woman who identifies as lesbian and fears she will be thrown out of her parents' home if they learn about her sexual orientation. Mesosystems refer to connections between various microsystems in which the youth actively participates. For example, a13-year-oldgay teen who attends church, is well-liked, and involved in extra-curricular activities will likely experience better outcomes than his classmate who also is gay, but is ostracized by his family and mosque, and is forbidden to participate in after school events. Exosystems are linkages in which adolescents are not directly involved but nonetheless affected by, such as administrative policies developed by school boards. If a student's parent is an active memberof the local Parent Teacher Organization (PTO) and the organization successfully pressures the school board to remove the Gay-Straight Alliance, her high school experience would be negatively impacted. Macrosystems consist of established cultural norms influencing individuals, and include political and societal context surrounding LGBQ youth. These may include institutional heterosexism, as well as various state and federal policies affecting their wellbeing. These connections serve as either 
barriers or supports to development. The quality and nature of these interactions affect adolescent outcomes. Chronosystems, changes over time, also impact adolescent development. For example, technological advances allow LGBQ youth to more easily connect with one another.

\section{Risk and resilience}

Risk and resilience theory is also helpful in explaining various outcomes for lesbian, gay, bisexual, and questioning youth. Risk refers to proximal (individual stressors) and/or distal (ecological or environmental) influences placing LGBQ youth in jeopardy for negative outcomes. These factors often occur simultaneously and can be additive or exponential [5]. Resilience is defined as the ability to successfully navigate hardship in spite of risk. Protective factors interrupt the trajectory from risk to negative outcome [6]. Risk factors for LGBQ youth include academic difficulties, anxiety, depression, relationship issues, and risky behaviors, such as unsafe sex and substance dependence $[3,7]$. Social support, a potent protective factor, includes interaction with encouraging adult role models. Contact with supportive adults, including mental health professionals, shields LGBQ youth from harm and promotes resilience.

\section{National Climate}

Culture and history have a considerable effect on public views of the LGBQ community. In certain times, organized religions determined society's view that homosexuality was a sin, while in othereras, same sex relationships were considered ordinary expressions of human sexuality. These perspectives are important, as they are the antecedents of present-day societal attitudes, including those of mental health professionals.

\section{Historical Context}

In the late 1800's, homosexuality was considered perverse. Sigmund Freud viewed homosexuality as pathological, attributing same sex attraction to narcissistic wounding before age five. He further posited homosexual identities were accompanied by Border line or Narcissistic Personality Disorders [8]. Homosexuality was included in the first Diagnostic Statistical Manualas a diagnosable psychiatric illness. Further, people who identified as gay, lesbian, or bisexual were deemed unfit to serve in the U.S. military [9].

During the 1960s and 1970 s, the LGBQ community responded to oppression to resistance. The Stonewall rebellion ignited the gay liberation movement. Police frequently raided Stonewall, a gay bar located in the Green wich Village section of New York City. In June of 1969, bar patrons confronted the police [10]. Capitalizing on this energy, activist organizations arose in major cities across the United States [11]. Among their victories was the removal of homosexuality as a codified, diagnosable mental illness in 1973 [12].

In the early 1980 s, the gay community was accused of starting the AIDS epidemic. The resultant surge in prejudice against gay men led to delayed prevention and treatment efforts [13]. Ryan White, a young child diagnosed following a blood transfusion, became the face of AIDS. Subsequently, attitudes about the virus began to shift. The Ryan White CARE (Comprehensive AIDS Resource Emergency) Act of 1990 financed community-based care and support [14]. The HIV/AIDS crisis coalesced the gay, lesbian, and bisexual communities. For instance, lesbians significantly contributed to care giving for those affected and forcefully protested the lack of governmental response [15].

The devastation from AIDSaccentuatedthe vital need for legal protections for the LGBQ community.Calls for marriage equity and changes in child custody lawsaccompanied advocacy to repeal the military ban and to protectemployment $[9,16]$. In 2013, the Supreme Court ruled on the case of the United States v Windsor, determining the federal government could no longer discriminate against same sex couples [17]. Two years later, the Supreme Court decided
Obergefell v. Hodges, affirming all states to recognize same-sex marriages [18].

Following the 1973 removal of "homosexual identification" as a mental disorder, the Department of Defense continued the service ban. In 1993, the Clinton administration enacted Don't Ask Don't Tell (DADT) policy, allowing LGBQ members of the armed force to continue service if they did not discuss their sexual orientation and did not engage in sexual activity. President Obama signed the repeal of DADT into law in 2010. Not only were LGBQ service members allowed to remain in the military, this new legislation permitted those who were discharged under DADT to rejoin $[19,20]$.

Until recently, many states and municipalities did not protect LGBQ employees. However, in June 2020, the United States Supreme Court held that Title VII protections afforded coverage to all, regardless of sexual orientation or gender identity. During his first day in office, President Joe Biden signed an Executive Order aimed at preventing and combatting discrimination linked to heterosexism (whitehouse. gov, 2021).

\section{Heterosexism}

Along with historical context, the socio-cultural environment impacts LGBQ youth. The experiences of LGBQ individuals across the lifespan are situated in pervasive heterosexism, a system of oppression stigmatizing members of the LGBQ community [12]. For example, many same sex couples are reluctant to show public affection without fear of verbal abuse and/or physical attack. Institutional heterosexism can be explicit or implied. The assumption that romantic relationships are heterosexual is an example of implicit bias. Hiring practices that exclude lesbians, gay men, and bisexuals at sectarian agencies are explicitly heterosexist. Structural barriers disadvantage LGBQ individuals who choose to aspire to managerial positions.

In addition, heterosexism can be overt or hidden. Covert heterosexism is synonymous with microaggressions. Sue and colleagues [21] defined microaggressions as casual comments and/or behaviors by people of privilege communicating disparaging messages to marginalized recipients. Microaggressions serve to demean and devalue individuals, whether or not they are intentional. For example, a lesbian adolescent may be told that since she was make-up, there is no way she can be gay. Consequences of microaggressions for LGBQ individuals include depression, low self-worth, and trauma [22]. Persistent discrimination at the socio-cultural level directly impacts physical and mental well-being. The perception of oppression, as well as actual experiences of discrimination, are correlated with low self-esteem, depression, and substance abuse among LGBQ youth $[7,23]$.

Practitioners play a critical role in advocating for LGBQ rights, including parity in the areas of health and mental health. Professionals can also raise client consciousness by connecting personal experience with broader sociopolitical influence. Similarly, they can help clients link their experiences with overt and covert heterosexism is linked to broader sociopolitical influences. For example, mental health workers can discuss how heterosexism and the resultant stigma and discrimination exacerbate individual stressors [3].

\section{Community Context}

Like historical and sociocultural climates, community environment also influences the lives of LGBQ individuals in the United States. Community as context, including its structure, climate, and culture, emphasizes the provision of risks and protective factors inhibiting or promoting resilience in its members [24]. For example, youth living in neighborhoods with high crime against LGBQ individuals are more likely to attempt suicide [25]. The perception of neighborhood intolerance, as described by $42 \%$ of LGBQ youth, is an example of community risk [26]., Specific formal resources, such as LGBTQ 
centers and events protect by providing of safe spaces for adolescents. Indirectly, these resources send a message of inclusivity [27].

Whether rural or urban. LGBQ youth have similar health and mental health needs. However, the experiences of youth living in rural areas are somewhat unique. In addition to reduced population density, rural residents have over whelmingly conservative political attitudes, as well as traditional religious values [28]. Thus, the social climate for LGBQ adolescents residing in rural areas is often more challenging.

The lack of formal resources and support networks in rural communities lead many LGBQ youth to experience social isolation [29]. For example, Rickard and Yancey [30] reported rural adolescents being less connected with the LGBQ community and having less general social support. These youth are often stigmatized and experience high levels of discrimination due to their sexual orientation [31]. Perceived community heterosexism is negatively related to sexual orientation disclosure and mental well-being [32]. Rural youth are at increased risk foranxiety, depression, and substance abuse as compared to those in urban areas [33]. The dearth of LGBQ specific resources in rural communities predicts substance abuse and criminal activity [34]. Due to lack of nearby facilities and fear of discriminatory treatment, these youth are less likely to seek assistance [35].

Although risks outweigh the positives for youth residing in rural areas the advantages of living in rural areas include lower crime rates and increased opportunities for outdoor recreation [36]. Social support, found within communities, may also lead to a sense of belonging associated with positive health and mental health outcomes [37]. Increased access to technology and various forms of social media allows greater opportunities to socialize with other LGBQ youth, there by providing emotional support [38].

Craig and McInroy [39] suggest specially designed community care networks also offer protection. As an alternative to traditional service delivery, these networks consist of cooperative and integrated services, there by improving access to this marginalized group. In addition, community care networks have the potential to bridge gaps in service utilization [40, 41]. Telemedicine is another approach that can buffer the disparity in outcomes for rural adolescents and emerging adults. During the Covid-19 pandemic, telehealth gained popularity as a vehicle for assessment and treatment of physical and mental health issues. This approach can help overcome geographic service barriers and remedy concerns about seeking in-person treatment [42]. Mental health professionals are encouraged to advocate for these networks and services in their communities.

\section{School Climate}

School climate is a multifaceted concept encompassing social norms, values, behavioral expectations, organizational structure, and physical environments $[43,44]$. Perception of the school environment, including experiences in the classroom, are predictive of students' educational, social and emotional outcomes [45]. Thus, establishing school environments with explicit norms, predictable routines, and support are essential for student well-being.

Research indicates LGBQ youth experience social exclusion, harassment, and assault at a much higher rate than their heterosexual counterparts [46]. The National School Climate survey, commissioned by the Gay, Lesbian \& Straight Education Network [47] surveyed nearly 17,000 LGBTQ youth and found 59.1\% felt unsafe at school due to sexual orientation and nearly one third stated they missed at least one day of school each month due to safety concerns. Nearly all of the participants heard heterosexist remarks, such as "dyke" or "faggot" in their schools, with more than half hearing those remarks from their teachers.

LGBQ identified adolescents are significantly more at risk for bullying than their heterosexual peers. Bullying, whether "traditional" or cy berbullying,manifestsin pooreracademicandpsychologicaloutcomes.
$[48,49]$. Educational impacts include increased absences, diminished engagement, heightened disciplinary issues, and lower levels of achievement [50]. LGBQ youth are also at higher risk for substance abuse and dependence, risky sexual behavior, self-harm, depression, and anxiety disorders [3, 51]. For example, Hatchel, et al. [52] found victimization by peers was related to suicidal ideation and attempt.

These negative effects last well into adulthood, particularly for students of color $[23,53,54]$. The intersection of race/ethnicity and sexual orientation puts students at higher risk for peer victimization [55]. Among Latinx LGBQ adolescents, bullying is related to increased episodes of and severity of depression [56]. Latinx LGBQ adolescents are almost twice as at risk of attempting suicide than their white peers and American Indian/Native Hawaiian/Pacific Islander bisexual youth are at nearly two-and a half times greater risk of suicidal gestures [57].

Often, LGBQ youth elect to keep silent about bullying. High school students believe administration would take no actionor the situation would escalate if they told [58]. Perceived bigotry has also been linked to failure to report. Too often, teachers and school administrators do not intervene, even when directly viewing victimization of LGBQ students $[59,60]$. Indeed, school professionals are generally uncomfortable when intervening with bullying specifically centered on sexual orientation [61]. This discomfort on the part of teachers and other staff has potentially deadly consequences for LGBQ students. For example, Goodenow [60] found victimization combined with perceived lack of support from school personnel predicted suicidality. Affirming school climates, however, are associated with more positive outcomes, including reduced drinking, lessened anxiety, and diminished symptoms of depression $[62,63]$.

LGBQ youth encounter a multitude of sexual health inequities, in a large part due to deficits in sex education [64]. Well-designed, inclusive sex education programs reduce risky sexual behavior and improve sexual health for youth. However, the Gay, Lesbian, Straight Education Network [47], found only $8.2 \%$ of students received inclusive health classes. This is especially distressing as research indicates LGBQ youth are more likely to engage in high-risk sexual behaviors than their heterosexual counter parts [65]. However, LGBQ adolescents in schools with inclusive sex education programs are significantly more likely to have fewer sexual partners, and less alcohol or other drug use [66].

Increased efforts focusing on more supportive school environments are essential. Mental health practitioners, school social workers, and counselors are obligated to work on a broad effort to make schools affirming places for LGBQ youth. Professionals can work directly with LGBQ high school students to assist them in dealing with the effects of bullying and other peer related problems they may be experiencing at school. Additionally, providers can facilitate psychoeducational groups for straight and LGBQ students promoting positive peer relationships. Mental health practitioners can also assist LGBQ clients by acknowledging heterosexism. For example, they can normalize same sex attraction with inclusive language on intake and other forms.

Mental health professionals need to work with faculty and administration to develop and streng then policies of zero tolerance for bullying [67]. Among the best-known and effective interventions are Gay/Straight Alliances (GSAs). Schools with GSAs provide a strong social support network to youth, thereby diminishing feelings of loneliness and isolation. The mere presence of a GSA effectively decreases bullying and promotes greater student well-being [6870]. Day and colleagues [71] found higher level of peer and teacher support and decreased bullying in schools with clear LGBTQfocused policies and the presence of GSAs. Gower, et al. [72] suggest LGBTQ supportive practices create a supportive school climate for all students. They can also advocate for the provision of safe and affirming spaces [39]. Professionals should also make certain they 
are well educated about policies specific to their school districts and states, and must work to eliminate barriers for inclusive, comprehensive sex education. Professionals can promote competency training for school staff and campaign for inclusion of LGBQ issues in the curriculum and professional development [73]. Additionally, mental health practitioners can advocate for collaboration with community partners in efforts aimed at implementing strategies to ameliorate this issue.

\section{Dating Relationships}

Adolescent development is marked with close friendships, dating, and intimate relationships. Dating provides adolescents with opportunities to discover sexual and emotional intimacy. These relationships are of particular importance to LGBQ youth who confront additional challenges to identity formation due to their oppressed status [74]. These adolescents face increased difficulties due limited potential dating partners, especially in rural communities. LGBQ youth confront intensified fear of rejection when asking someone out, as they have the additional concern about whether their potential date has the same sexual orientation [75].

Marginalized youth are at heightened risk of intimate partner violence, including emotional, physical, and sexual abuse. According to the 2017 Youth Risk Behavior Survey (YRBS), 25\% of LGBQ youth experience sexual dating violence and $18 \%$ physical dating violence [76]. Unlike their heterosexual counterparts, LGBQ adolescents are at additional risk for being "outed "by a current or former romantic partner. When LGBQ youth do recognize intimate partner violence, they are significantly less likely to seek services due to fear of rejection by service providers [76]. In fact, the National Coalition Against Domestic Violence (NCADV, 2020) found less than $5 \%$ of LGBQ victims of intimate partner violence sought protective orders.

Practitioners can support young lesbians, gay men, bisexual, and questioning individuals by providing information and support about negotiating successful dating relationships and advocating for services promoting physical, sexual, and emotional health. Providers should also proactively engage LGBQ youth in antiviolence outreach. Additionally, mental health workerscan offer relationship enhancing skills groups for LGBQ youth [78]. Service providers can also offer information on same sex relationships in sex education classes. Finally, mental health practitioners can help shift the narrative of intimate partner violence as exclusively heterosexual and educate and advocate for inclusive policies [79].

\section{Family Context}

Family relationships, especially those with parents, are significant to an adolescent's experience. Although appropriate connectedness with families is associated with emotional health, LGBQ youth are at increased risk to be abandoned by family. For LGBQ youth, parental support predicts higher levels of emotional well-being, lower incidence of illegal drug use, and less likelihood of experiencing interpersonal violence [80, 81]. Conversely, LGBQ young adults who experience family rejection in adolescence are eight times more likely to attempt suicide, almost six times more likely to have high levels of depression, and more than three times more likely to use illegal drugs and/or have unprotected sex than those who reported little or no parental rejection [82]. Additionally, parental rejection is a powerful predictor of internalized sexual stigma [83].

Parental reactions to a child's disclosure of sexual orientation range from total acceptance to feelings of despair. Race/ethnicity, socioeconomic status, and religiosity influence likelihood of familial support. Given the shifts in sociocultural attitudes about the LGBQ community, more parents are reacting to their children's coming out stories with acceptance.

However, politically conservative and religiously fundamental parents may experience cognitive dissonance, on the one hand feeling love for their child and on the other, holding negative views about LGBQ individuals [84]. Parents also face the potential for rejection from extended family and friends [85].

Mental health professionals are uniquely able to educate and support LGBQ youth and their families. Specifically, providers can support LGBQ adolescents in disclosing to parents and offer education about sexual orientation, giving evidence-based suggestions on be an effective support. Practitioners can also educate families about the potential deleterious effects of negative reactions. Further, they can provide counseling on integrating political values and religious beliefs which may not be in concert with their child's sexual orientation. Providers must also be sensitive to racial/ethnic and socio-economic variations and their potential impact on parental support.

\section{Impact of Environmental Risk}

Compared to heterosexual adolescents, LGBQ youth have an increased risk of victimization in their communities, schools, peer groups, and families. Heterosexism, disparities in access to care, bullying, and lack of family acceptance, put these youth at risk for mental, physical, sexual health consequences, victimization, substance abuse disorders, and homelessness. Those with intersecting identities are at increased risk for negative outcomes.

\section{Homelessness}

Family conflict over an adolescent's sexual orientation is significantly associated with homelessness or need for out of home care [86]. In the United States, nearly $20 \%$ to $40 \%$ of homeless youth are LGBQ youth; considering only $4 \%$ to $10 \%$ of the total youth population identifies as non-heterosexual, this rate is clear evidence of the disproportionality of homelessness among LGBQ youth [87]. Corliss, et al. [88] found approximately $25 \%$ of lesbian and gay high school students and $15 \%$ of bisexual students reported recent or current homelessness. In fact, Cutilli, et al. [89] reported LGBQ youth were $143 \%$ more likely to be homeless than their heterosexual peers. Slightly over $75 \%$ of LGBQ youth report having slept outdoors at least once while they have been homeless and only $25 \%$ report ever having used emergency shelters. These youth also are likely to remain homeless for longer periods of time [90]. Lesbian and bisexual female youth and gay and bisexual males were equally likely to either run away or be evicted from their family home [91]. LGBQ youth of color (YOC) are more than six times more likely to become homeless than their white counterparts [92].

Homeless LGBQ youth are at increased risk for psychological distress and substance abuse than are their heterosexual homeless counterparts. They also report higher levels of depressive symptoms, including suicidal ideation, and substance abuse [91, 93]. Young bisexual and gay men who live on the streets are at increased risk for intravenous drug use [94]. Homeless lesbian and bisexual young women are at higher risk for suicidal ideation and substance abuse [95]. LGBQ youth also are more likely to trade sex for food and cash [96]. Homelessness has long lasting consequences, including an increased risk of future stress ful life events and negative social relationships, even when housing security is attained [91].

Effective prevention and intervention strategies is needed to support homeless LGBQ youth. Efforts to intercede with families to assist with disclosure of sexual orientation are one such preventative measure. When indicated, practitioners can help manage family reunification [97]. However, for other youth, moving back home is not tenable. Mental health professionals should assist in making shelters and transitional living programs accessible and safe for LGBQ youth, including working with staff and administration to offer targeted trainings. Service providers can also advocate for policies prohibiting discrimination of services to LGBQ youth, as well as specific funding to serve this population.

\section{Foster Care}

Family rejection and physical victimization by family members not only place youth at risk for homelessness, but also entry into the 
child welfare system. LGBQ youth are disproportionately over represented in the foster care systemand are at increased risk for disrupted placements and relocation to congregate care [98, 99]. These living situations place youth at further risk for victimization by residents and staff. LGBQ youth in the child welfare system do not improve while in care; rather, they become victims of violence, harassment, and discrimination [100]. It is common for these to be segregated and placed in individual bed rooms due to fears of placing them with same sex peers. In addition, those in group home placements are significantly less likely to achieve permanency [59]. Attitudes of foster families, individual child welfare workers, and group home staff, as well as structural barriers, including policies, prevent LGBQ youth from finding affirming placements.

Mental health practitioners can assist LGBQ youth in foster care through individual counseling, acknowledging past abuse, heterosexism, and experiences with discrimination. Service providers canprovide pre-service and in-service trainings to give foster parents the necessary knowledge, skills, and support to ensure youth resilience. They can provide training for child welfare workers as well. Professionals can also advocate for state, federal, and administrative policies protecting LGBQ youth in foster care, including increased efforts in placing children in family-centered care.

\section{Mental Health/Substance Abuse}

Mental health and substance abuse disorders are substantially more prevalent among LGBQ youth. These youth report heightened symptoms of anxiety, depression, suicidal ideation, and self- harm compared to heterosexual youth [3]. The intersecting dynamics of heterosexism, sexism, and racism put lesbian youth and youth of color are at increased risk for depression and anxiety [7]. Bostwick and colleagues [101] found American Native/Pacific Islander, Latinx, and multiracial youth are at significantly higher risk of suicidal attempts than other racial/ethnic minority youth. LGBQ adolescents are also twice as likely to abuse alcohol and other drugs than their heterosexual peers, with lesbian and bisexual women over four times more likely to use illegal drugs [102, 103]. LGBQ adolescents are also twice as likely to smoke cigarettes than their heterosexual counterparts [104].

Mental health professionals are able to minimize the risk to LGBQ youth. Careful assessment, including risk and protective factors, should be completed. Identifying the number and potency of risk factors, rather than solely on the presenting problem, are importantin the development of effective intervention [7]. Additionally, practitioners need to identify areas of individual strength and support capacity for change. Practitioners must also understand the impact of historical, political, and cultural context in the development of stigma and community resilience. Understanding contextual influences contributing to mental health issues and developing safe clinical spaces for LGBQ youth are also essential [105]. In addition to attending professional training on work with LGB youth, providers are encouraged to work with social work, counseling, and other programs preparing mental health practitioners and advocating for inclusion of LGBQ content in the training of future professionals.

\section{Conclusion}

Historical, political, and cultural contexts contribute to the risk of adverse outcomes for LGBQ adolescents. Heterosexism intersecting with racism, sexism, and religious bias, negatively impact LGBQ youth of color, those holding non-Christian beliefs, and/lesbian and bisexual women. Community environment also can create barriers or supports. Developmentally, adolescents are most affected by school experiences, peer and romantic connections, and family relationships. Placement in foster care, homelessness, mental health and substance abuse are among adverse consequences for LGBQ youth. Mental health professionals' appreciation of the impact of diverse needs and experiences of LGBQ youth, combined with use of affirmative practice skills, has the ability to protect youth and shift the narrative from risk to resilience.
Conflict of interests: The authors declare no conflict of interest. References

1. D'amico, E., Julien, D., Trembley, N., \& Chartrand, E. (2015). Gay, lesbian, bisexual youths coming out to their parents: Parental reactions and youthoutcomes. Journal of GLBT Family Studies, 11(5), 411-437, doi 10.1080/1550428X.2014.981627

2. Gambron, T.B. \&Gerwitz O'Brien, J.R. (2020). Runaway youth: Caring for the nation's largest segment of missing children. Pediatrics, 145 (2), 1-12. 10.1542/peds.2019-3752

3. Russell, S.T. \& Fish, J.N (2016). Mental health in lesbian, gay, bisexual, and transgender youth. Annual Review of Clinical Psychology, 12 (1), 465-487. 10.1146/annurevclinpsy-021815-093153

4. Bronfenbrenner, U. (1977). Toward an experimental ecology of human development. American Psychologist, 513-531. 10.1037/0003-066x.32.7.513

5. Shilo, G., Antebi, N. \&Mor, Z. (2015). Individual and community resilience factors among lesbian, gay, bisexual, questioning, and youth and adults in Israel. American Journal of Community Psychology, 55 (1/2), 215-227. 10.1007/s10464014-9693-8

6. Van Breda, A.D. \& Theron, L.C. (2018). A critical review of South African child and youth resilience studies, 2009-2017. Children and Youth Service Review, 91, 237-247. 10.1016/j. childyouth.2018.06.022

7. Craig, S.L. \& McInroy, L.B. (2013). The relationship of cumulative stressors, chronic illness, and abuse to self-reported suicide risk of Black and Hispanic sexual minority youth. Journal of Community Psychology, 41 (7), 783-798. 10.1002/ jcop. 2157

8. Dreschler, J. (2008). A history of homosexuality and organized psychoanalysis. Journal of the American Academy of Psychoanalysis and Dynamic Psychiatry, 36 (3), 443-460. 0.1521/jaap.2008.36.3.443

9. Rimmerman, C.A. (2015). Gay rights, military wrongs: Political perspectives of lesbians and gays in the military. New York, Routledge. 10.4324/9780429492792-4

10. Faderman, L. (2015). The gay revolution: The story of the struggle. New York, NY: Simon \& Schuster.

11. Armstrong, E. A. \&Crage, S.M. (2006). Movements and memory: The making of the Stonewall myth. American Sociological Review, 71 (5), 724-751. 1015-1031.

12. Herek, G. M. (2004). Beyond homophobia: Thinking about sexual prejudice and stigma in the twenty-first century. Journal of Sexuality Research and Social Policy, 1 (2), 6-24.

13. Herek, G. \&Capitanio, J.P. (1999). AIDS stigma and sexual prejudice. American Behavioral Scientist, 42 (7), 1106-1116. 10.1177/0002764299042007006

14. Cahill, S. R., Mayer, K.H., \& Boswell, S.L. (2015). The Ryan White HIV/AIDS program in the age of health care reform. American Journal of Public Health, 105 (6), 1078-1085. 10.2105/ajph.2014.302442

15. Hutchison, B. (2015). Lesbian blood drives as communitybuilding activism in the 1980s. Journal of Lesbian Studies, 19(1), 117-128. 10.1080/10894160.2015.968079

16. Lind, A. (2004). Legislating the family: Heterosexual bias in social welfare policy frameworks. Journal of Sociology and Social Welfare, 31 (4), 21-35. 10/1080/014180303200031599

17. Ciocchetti, C. (2014). Teaching United States v. Windsor: The Defense of Marriage Act and its constitutional implications. Journal of Legal Studies Education, 31(2), 249-289. 10.1111/ jlse. 12016 
18. Knauer, N. J. (2018). Implications ofObergefell for samesex marriage, divorce, and parental rights. In Abbie E. Goldberg \& Adam P. Romero (Eds.)LGBTQ divorce and relationshipdissolution: Psychological and legal perspectives and implications for practice.(7-30). Oxford University Press. 10.1093/med-psych/9780190635176.003.0002

19. Alford, B. \& Lee, S.J. Toward complete inclusion: Lesbian, gay, bisexual and transgender military service members after repeal of Don't Ask, Don't Tell. Social Work, 61 (3), 257-265. 10.1093/sw/sww033

20. Connell, C. (2015). Right to serve or responsibility to protect? Civil rights framing and the DADT repeal. Boston University Law Review, 95(3), 1015-1028.

21. Sue, D. W., Capodilupo, C. M., Torino, G. C., Bucceri, J. M., Holder, A. B., Nadal, K. L., \&Esquilin, M. (2007). Racial microaggressions in everyday life. American Psychologist, 62(4), 271-286. 10.103770003-066X.624.271

22. Nadal, K.L. (2019). A decade of microaggressions research and LGBTQ communities: An introduction to the special issue. Journal of Homosexuality, 66 (10), 1309-1316. 10.1080/00918369.2018.1539582

23. Almeida, J., Johnson, R.M., Corliss, H.L., Molnar, B. E., \&Azreal, D. (2009). Emotional distress among LGBT youth: The influence of perceived discrimination based on sexual orientation. Journal of Youth and Adolescence, 38 (7), 10011014.10.1007/s10964-009-9397-9.

24. Chaskin, R.J. (2008). Resilience, community, and resilient communities: Conditioning contexts and collective action. Child Care in Practice, 14 (1), 65-74. 10.1080/13575270701733724

25. Duncan, D.T. \&Hatzenbuehler, M.L. (2014). Lesbian, gay, bisexual, and transgender hate crimes and suicidality among a population-based sample of sexual-minority adolescents in Boston. American Journal of Public Health, 104 (2), 272-278. 10.2015/alph.2013.301424

26. Human Rights Campaign (2012). Growing up LGBT in America. Washington, DC: N.A. Retrieved from: https://www. hrc.org/resources/youth-report

27. Eisenberg, M.E., Mehus, C.J., Saewyc, E.M., Corliss, H.L., Gower, A.L., Sullivan, R. \& Porta, C.M. (2018). Helping young people stay afloat: A qualitative study of community resources and supports for LGBTQ adolescents in the United States and Canada. Journal of Homosexuality, 65 (8), 969-989. 10.1080/00918369.2017.1364944

28. Dahl, A.L., Scott, R.k, \& Peace, Z. (2015). Trials and triumph: Lesbian and gay young adults raised in a rural context. Social Sciences, 4 (4), 1-15. 10.3390/socsci4040925

29. Oswald, R. F., \&Culton, L. S. (2003). Under the rainbow: Rural gay life and its relevance for family providers. Family Relations: An Interdisciplinary Journal of Applied Family Studies, 52(1), 72-81. 10.1111/j.1741-3729.2003.00072.x

30. Rickard, A., \& Yancey, C. T. (2018). Rural/non-rural differences in psychosocial risk factors among sexual minorities. Journal of Gay and Lesbian Social Services, 30 (2), 154-171. $10.1080 / 10538720.2018 .1444525$

31. Swank, E., Frost, D. M., \& Fahs, B. (2012). Rural location and exposure to minority stress among sexual minorities in the United States. Psychology and Sexuality, 3(3), 226-243. 10.1080/19419899.2012.700026

32. Kavanaugh, S. A., Taylor, A.B., Stuhlsatz, G.L., Neppl, T.K., \& Lohman, B.J. (2020). Family and community support among sexual minorities of color: The role of sexual minority identity and outness on psychological well-being. Journal of GLBT Family Studies, 16 (1), 1-17. 10.1080/1550428x.2019.1593279
33. Cohn, T. \&Leake, V. (2012). Affective distress among adolescents who endorse same-sex attraction: Urban versus rural differences and the role of protective factors. Journal of Gay and Lesbian Mental Health, 16 (4), 291-305. 10.1080/19359705.2012.690931

34. Dennis, J.P. (2019). Nothing out there: Community awareness and delinquency among gay and lesbian youth. Journal of LGBT Youth, 16 (1), 1-17. 10.1080/19361653.2018.1524320

35. Barefoot, K. N., Smalley, K. B., \& Warren, J. C. (2015). Psychological distress and perceived barriers to care for rural lesbians. Journal of Gay \& Lesbian Mental Health, 19(4), 347369. 10.1080/19359705.2015.1041629

36. Hash, K. M. \& Morrow, D.F. (2020). Lesbian, gay, bisexual, and transgender persons aging in rural areas. The International Journal of Aging and Human Development 90(2) 201-208. 10.1177/0091415019836110

37. Bowling, J., Vercruysse, C., Bello-Ognu, F., Krinner, L.M., Greene, T., Webster, C., \& Dahl, A.A. (2020). "It's the nature of the beast": Community resilience among gender diverse individuals. Journal of Community Psychology, 48 (7), 21912207. 10.1002/jcop.22371

38. Craig, S.L., Eaton, A.D., McInroy, L.B., Leung, V. Y.W., \& Krishnan, S. (2021). Can social media participation enhance LGBTQ+ youth well-being? Development of the social media development scale. Social Media and Society, 7 (1), $10.1177 / 2056305121988931$

39. Craig, S.L. \& McInroy, L.B. (2018). Building strengths-based and empowering continuums of care for LGBTQ youth. In Michael P. Dentato (Ed.), Social Work Practice with the LGBTQ Community: The Intersection of Historical, Health, Mental Health, and Policy Factors.(366-382).

40. Craig, S.L. (2011). Precarious partnerships: Designing a community needs assessment to develop a system of care for gay, lesbian, bisexual, transgender, and questioning (GLBTQ) youth. Journal of Community Practice, 19 (3), 1-18. 10.1080/10705422.2011.595301

41. Dentato, M.P., Craig, S.L., \& Smith, M. (2010). The vital role of social workers in community partnerships: The alliance for gay, lesbian, bisexual, transgender youth. Child and Adolescent Social Work Journal, 22 (5), 323-334. 0.1007/s10560-010-0210-0

42. Whaibeh, E., Mahmoud, H., \& Vogt, E.L. (2019). Reducing the treatment gap for LGBT mental health needs: The potential of telepsychiatry. The Journal of Behavioral Health Services and Research, 47 (3), 424-431. 10.1007/s11414-019-09677-1

43. Kim, H.Y., Schwartz, K., Capella, E. \& Seidman, E. (2014). Navigating middle grades: Role of social contexts in middle grade school climate. American Journal of Community Psychology, 54 (1-2), 28-45. 10.1007/s10464-014-9659-x

44. Thapa, A., Cohen, J., Guffey, S. \& Higgins-D'Alessandro, A. (2013).Areview ofschoolclimateresearch.Review of Educational Research, 83(3), 357-385. 10.3102/0034654313483907

45. Yang, C., Chan, M.K., \& Ma, L. (2020). School-wide emotional learning (SEL) and bullying victimization: Moderating role of school climate in elementary, middle, and high schools. Journal of School Psychology, 82, 49-69. 10.1016/j.jsp.2020.08.002

46. Kosciw, J., Palmer, N., Kull, R., \&Greytak, E. (2013). The effect of negative school climate on academic outcomes for LGBT youth and the role of in-school supports. Journal of School Violence. 12 (1), 45-63. 10.1080/15388220.2012.732546

47. Gay, Lesbian, and Straight Network (2019) The 2019 National School Climate Survey: The Experiences of Lesbian, Gay, Bisexual, Transgender, and Queer Youth in Our Nation's Schools. Retrieved January 29, 2021 https://www.glsen.org/ sites/default/files/2020-11/NSCS19-111820.pdf 
48. Kahle, L. (2020). Are sexual minorities more at risk? Bullying victimization among lesbian, gay, bisexual, and questioning youth. Journal of Interpersonal Violence, 35 (21/22), 49604978. 10.1177/0886260517718830

49. Ybarra, M.L., Mitchell, K.J. Kosciw, J.G.\&Korchmaros, J.D. (2015). Understanding linkages between bullying and suicidal ideation in a national sample of LGB and heterosexual youth in the United States. Prevention Science, 16 (3), 451-462. 10.1007/ s11121-014-0510-2.

50. Russell, S.T. (2008). Beyond risk: Resilience in the lives of sexual minority youth. Journal of Gay and Lesbian Issues, 2 (3), 5-18. 10.1300/J367v02n03_02.

51. Hong, J.S., Voisin, D.R., Cho, S., \&Espelage, D.L. (2016). Association among subtypes of bullying status and sexually risky behaviors of urban African American adolescents in Chicago. Journal of Immigrant and Minority Health. 18 (5). 10.1007/s10903-016-0375-5

52. Hatchel, T., Espelage, D., \&Merrin, G.J. (2019). Peer victimization and suicidality among LGBTQ youth: The roles of school belonging, self-compassion, and parental support. Journal of LGBT Youth, 16 (2), 134-156. $10.1080 / 19361653.2018 .1543036$

53. Craig, S. L., Austin, A. \& McInroy, L.B. (2013). School-based groups to support multiethnic sexual minority resiliency: Preliminary effectiveness. Child and Adolescent Social Work Journal, 30 (4), 4-22. 0.1007/s10560-013-0311-7

54. Greene, D. C., Britton, P. J., \& Fitts, B. (2014). Long-term outcomes of lesbian, gay, bisexual, and transgender recalled school victimization. Journal of Counseling \& Development, 92(4), 406-417. 10.1002/j.1556-6676.2014.00167.x

55. Jackman, K., Kreuze, E.J., Caceires, B.A., \&Schnall, R. (2020). Bullying and peer victimization of minority youth: Intersections of sexual identity and race/ethnicity. Journal of School Health, 90 (5), 368-377. 10.1111/josh.12883

56. Lardier, D.T., Pinto, S.A., Brammer, M.K., Garcia-Reid, P., \& Reid, R.J. (2020). The relationship between queer identity, social connection, school bullying, and suicidal ideation among youth of color. Journal of LGBT Issues in Counseling, 14 (2). 74-99. 10.1080/15538605.2020.1753623

57. Baiden, P., LaBrenz, C.A., Asiedua-Baiden, G., \&Muehlenkamp, J. J. (2020). Examining the intersection of race/ethnicity and sexual orientation on suicidal ideation and suicide attempt among adolescents: Findings from the 2017 Youth Risk Behavior Survey, Journal of Psychiatric Research, 125, 13-20. 10.1016/j.psychires.2020.02.029

58. Sherriff, N.S., Hamilton, W.E., Wigmore, S., \&Giambrone, B. (2014). "What do you say to them? Investigating and supporting the needs of lesbian, gay, bisexual, trans, and questioning (LGBTQ) young people. Journal of Community Psychology, 39 (8). 939-955. 10.1002/jcop.20479

59. Elze, D. (2014). LGBTQ youth and their families. In G. P. Mallon \& P. M. Hess (Eds.), Child Welfare for the 21 st century: A Handbook of Practices, Policies, and Programs, 2ndedition New York: Columbia University Press, 158-178. 10.7312/mall15180

60. Goodenow, C., Szalacha, L., \& Westheimer, K. (2006). School support groups, other school factors, and the safety of sexual minority adolescents. Psychology in the Schools, 43 (5), 573589. $10.1002 /$ pits. 20173

61. Bradshaw, C.P., Waasdorp, T.E., \&O’Brennan, L.M. (2013). Teachers' and education support professionals' perspectives on bullying and prevention: Findings from a National Education Association study. School Psychology Revie, 42 (3), 280-297. 10.1080/02796015.2013.12087474

J Ment Health Soc Behav

Volume 3.2021. 135
62. Colvin, S., Egan, J.E, \& Coulter, R.W.S. (2019). School climate and sexual and gender minority mental health. Journal of Youth and Adolescence, 48, 1938-1951. 10.1007/s10964-019-01108-w

63. Coulter, R.W. S., Birkett, M., Corliss, H.L., Hatzenbuehler, M.L., Mustanski, B., \& Stahl, R.D. (2016), Associations between LGBTQ-affirmative school climate and adolescent drinking behaviors. Drug and Alcohol Dependence. 161,340347. 10.1016/jdrugalcdep.2016.02.022

64. Mustanski, B., Greene, G.J., Ryan, D., \& Whitton, S.W. (2015). Feasibility, acceptability, and initial efficacy of an online sexual health promotion program for LGBT youth: The queer sex ed intervention. The Journal of Sex Research, 52 (2), 220-230. 10.1080/00224499.2013.867924

65. Travers, M., Murray, L. \& Kull, M. (2020). Sexual health and risk-taking behaviors among New York City high school students: Variation by sexual orientation and gender identity status. Journal of LGBT Youth10.1080/19361653.2020.1795776

66. Garg, N. \&Volerman, A. (2021). A national analysis of state policies on lesbian, gay, bisexual, transgender, and questioning/ queer includive sex education. Journal of School Health, 91 (2), 164-175. 10.1111/josh.12987

67. Mishna, F., Newman, P. A., Daley, A., \& Solomon, S. (2009). Bullying of lesbian and gay youth: A qualitative investigation. British Journal of Social Work, 39(8), 1598-1614.10.1093/bjsw/ bcm148

68. Chong, E.S.K., Poteat, V.P., Yoshikawa, H., \&Calzo, J.P. (2019). Fostering youth self-efficacy to address transgender and racial diversity issues: The role of the gay-straight alliances. School Psychology, 34 (1), 54-63. 10.1037/spq0000258

69. Toomey, R., Ryan, C., Diaz, R., \& Russell, S. (2011). High school gay-straight alliances (GSAs) and adult well-being: An examination of GSA presence, participation, and perceived effectiveness. Applied Developmental Science, 15 (4), 175-185. 10.1080/1088869.2011.607378

70. Walls, N. E., Kane, S. B., \&Wisneski, H. (2010). Gay-straight alliances and school experiences of sexual minority youth. Youth and Society, 41(3), 307-331. 10.1177/0044118X09334957

71. Day, J.K., Fish, J.N., Grossman, A.H., \& Russell, S.T. (2020). Gay-straight alliances, inclusive policy, and school climate: LGBTQ youths' experiences of social support and bullying. Journal of Research and Adolescence, 30 (52), 418-430. 10.1111/jora. 12487

72. Gower, A.L., Foster, M., Gloppem, K., Eisenberg, M.E., Borowsky, I.W., Johnson, A.Z., \&Connett, J.E. (2018). School practices to foster LGBT supportive climate: Associations with adolescent bullying involvement. Prevention Science, 19 (6), 813-821. 10.1007/s11121-017-0847-4

73. Kolbert, J.B., Crothers, L.M., Bundik, M.J., Wells, D.S., Buzgon, J., Berbary, C., Simpson, J., \& Senko, K. (2015). Teachers' perceptions of bullying of lesbian, gay, bisexual, transgender, and questioning (LGBTQ) students in a southwestern Pennsylvania sample. Behavioral Science, 5 (2), 247-263. 10.3390/bs5020247

74. Bauermeister, J. A., Johns, M. M., Sandfort, T. M., Eisenberg, A., Grossman, A. H., \&D'Augelli, A. R. (2010). Relationship trajectories and psychological well-being among sexual minority youth. Journal of Youth \& Adolescence, 39(10), 11481163. 10.1007/s10964-010-9557-y

75. Chorney, D. B., \& Morris, T. L. (2008). The changing face of dating anxiety: Issues in assessment with special populations. Clinical Psychology: Science \& Practice, 15(3), 224-238. 10.1111/j.1468-2850.2008.00132.x 
76. Kann, L., McManus, T., Harris, W.A., Shanklin, S.L., Flint, K.H., Queen, B., Lowry, R. Chyen, D., Whittle, L., Thornton, J., Lim, C., Bradford, D., Yamakawa, Y., Leon, M., Brener, N., \&Ethier, K.A. (2018). Youth Risk Behavior Surveillance Survey 2017 MMWR Surveillance 67 (8), 1-114. 10.15585/mmwr. ss6708a1

77. Luo, F., Stone, D. M., \& Tharp, A. T. (2014). Physical dating violence victimization among sexual minority youth. American Journal of Public Health, 104(10), e66-e73. 10.2105/ AJPH.2014.302051

78. Starks, T., Newcomb, M., \&Mustanski, B. (2015). A longitudinal study of interpersonal relationships among lesbian, gay, and bisexual adolescents and young adults: Mediational pathways from attachment to romantic relationship quality. Archives of Sexual Behavior, 44(7), 1821-1831. 10.1007/s10508-015-04926

79. Hudson, N. (2019). Family violence laws: Traditional narratives and the (in)visibility of lesbian relationships and lesbianparented families. Journal of Lesbian Studies, 23 (3), 357-382. 10.1080/10894160.2019.1599241

80. Horwitz, A.G., Grupp-Phelan, J., Brent, D., Barney, B.J., Casper, T.C., Berona, J., Chernick, L.S., Shenoi, R., Cwik, M., King, C.A., \& Pediatric Emergency Care Applied Research Network (2021). Risk and protective factors for suicide among sexual minority youth seeking emergency medical services. Journal of Affective Disorders, 279, 274-281. 10.1016/j.jad.2020.10.015

81. Roe, S. (2017). Family support would have been like amazing": LGBTQ youth experiences with parental and family support. The Family Journal: Counseling and Therapy for Couples and Families 25(1), 55-62. 10.1177/1066480716679651

82. Ryan, C., Huebner, D., Diaz, R. M., \& Sanchez, J. (2009). Family rejection as a predictor of negative health outcomes in White and Latino lesbian, gay, and bisexual young adults. Pediatrics, 123, (1), 346-352. 10.1542/peds.2007-3524

83. Baiocco, R. Fontanesi, L., Santamaria, F. Ioverno, S. Baumgartner, E. \&Laghi, F. (2016). Coming out during adolescence: Perceived parents' reactions and internalized stigma. Journal of Health Psychology, 21(8), 1809-1813. $10.1177 / 1359105314564019$

84. Conley, C. (2011). Learning about a child's gay or lesbian sexual orientation: Parentalconcerns about societal rejection, loss of loved ones, and child well-being. Journal of Homosexuality, 58 (8), 1022-1040. 10.1080/00918369.2011.598409

85. D'amico, E., Julien, D., Tremblay, N., \& Chartrand, E. (2015). Gay, lesbian, and bisexual youths coming out to their parents: Parental reactions and youths' outcomes. Journal of GLBTFamily Studies, 11(5), 411-437. 10.1080/155042x.2014.9816273756

86. Ream, G.L. \& Forge, N. (2014). Homeless lesbian, gay, bisexual, and transgender (LGBT) youth in New York City: Insights from the field. Child Welfare, 93 (2), 7-22.

87. Cunningham, M., Pergamit, M., Astone, N., \& Luna, J. (2014). Homeless LGBTQ youth. Washington, DC: Urban Institute, Retrieved on February 4, 2021 from: https:/www.urban. org/sites/default/files/publication/22876/413209-HomelessLGBTQYouth.PDF

88. Corliss, H.L., Goodenow, C.S., Nichols, L., \& Austin, S.B. (2011). High burden of homelessness among sexual minority adolescents: Findings from a representative Massachusetts high school sample. American Journal of Public Health, 101 (9), 1683-1689. 10.2105/AJPH.2011.300155

89. Cutilli, J.J., Treglia, D., \&Herbers, J.E. (2020). Adolescent homelessness and associated features: Prevalence and risk across eight states. Child Psychiatry and Human Development. 51 (1). 48-58. 10.1007/s10578-019-00909-1
90. Choi, S. K., Wilson, B. D. M., Shelton, J., Gates, G. (2015). Serving our youth 2015: The needs and experiences of lesbian, gay, bisexual, transgender, and questioning youth experiencing homelessness. The Williams Institute. Available online at: http:// escholarhips.org/uc/item/1pd9886n

91. Rosario, M., Scrimshaw, E., \& Hunter, J. (2012). Homelessness among lesbian, gay, and bisexual youth: Implications for subsequent internalizing and externalizing symptoms. Journal of Youth and Adolescence, 41 (5), 544-560. 10.1007/s1096401109681-3

92. Siconolfi, D., Tucker, J.S., Shadel, W.G., Seelam, R. \&Golinelli, D. (2020). Health, homelessness severity, and substance use among sexual minority youth experiencing homelessness: A comparison of bisexual versus gay and lesbian youth. The Journal of Sex Research, 57 (7), 933-942. 10.1080/00224499.2019.1695723

93. Keuroghlian, A.S., Shtasel, D., \&Bassuk, E.L. (2014). Out on the street: A public helath and policy agenda for lesbian, gay, bisexual, and transgender youth who are homeless. The American Journal of Orthopsychiatry, 84 (1), 66-72. 10.1037/ h0098852

94. Kipke, M.D., Weiss, G., \& Wong, C.F. (2007). Residential status as a risk factor for drug use and HIV risk among young men who have sex with men. AIDS and Behavior, 11 (6 supplement), S59-S69.

95. Walls, N. E., Kane, S. B., \&Wisneski, H. (2007). Differentiating the social service needs of homeless sexual minority youths from those of non-homeless sexual minority youths. Journal of Children and Poverty, 13 (2), 177-205. 10.1080/10796120701520309

96. Tyler, K.A. \& Schmitz, R.M. (2018). A comparison of risk factors for various forms of trauma in the lives of lesbian, gay, bisexual, and heterosexual homeless youth. Journal of Trauma and Dissociation, 19 (4). 431-443. 10.1080/15299732.2018.1451971

97. Castellanos, H.D. (2016). The role of institutional placement, family conflict, and homosexual pathways among Latino LGBT youth in New York City, Journal of Homosexuality, 63 (5), 601632. 10.1080/00918369.2015.1111108

98. Baams, L., Wilson, B., \& Russell, S.T. (2019). LGBTQ youth in unstable housing and foster care. Pediatrics, 143 (3) e20174211. 10.1542 peds.2017-4211

99. Durso, L.E., \& Gates, G.J. (2012). Serving our youth: Findings from a national survey of service providers working with lesbian, gay, bisexual, and transgender youth who are homeless or at risk of becoming homeless. Los Angeles: The Williams Institute with True Colors Fund and The Palette Fund. Retrieved 2.4.21 https://escholarship.org/uc/item/80x75033

100. McCormick, A., Schmidt, K. \& Terrazas, S. (2017). LGBTQ youth in the child welfare system: An overview of research, practice, and policy. Journal of Public Child Welfare, 11(1), 2739. 10/1080/15548732.2016.1221368

101. Bostwick, W.B., Meyer, I., Aranda, F., Russell, S., Hughes, T., Birkett, M., \&Mustanski, B. (2014). Mental health and suicidality among racially/ethnically diverse sexual minority youths.American Journal of Public Health, 104 (6), 1129-1136. 10.2015/ajph.2013.301749

102. Marshall, M.P., Friedman, M.S., Stall, R. King, K.M., Miles, J., Gold, M.A., \& ...Morse, J.O. (2008). Sexual orientation and adolescent substance use: a meta-analysis and methodological review. Addiction, 103 (4), 546-556. 10.1111/j.13600443.2008.02149.x 
103. Watson, R.J., Goodenow, C., Porta, C., Adjei, J., \&Saewyc, E. (2018). Substance use among sexual minorities: Has it actually gotten better? Substance Use and Misuse, 53 (7), 1221-1228. 10.1080/10826084.2017.1400563

104. King, B.A., Dube, S.R., \& Tyan, M. (2012) Current tobacco use among adults in the United States: Findings from the National Adult Tobacco Survey. American Journal of Public Health, 102 (11). 93-100. 10.2105/AJPH.2012.301002
105. McClain, Z., Hawkins, L. A., \& Yehia, B. R. (2016). Creating welcoming spaces for lesbian, gay, bisexual, and transgender (LGBT) patients: An evaluation of the healthcare environment. Journal of Homosexuality, 63(3), 387393.10.1080/00918369.2016.1124694 